SOTO, Hernando de. O Mistério do Capital. Rio de Janeiro: Editora Record, 2011. Cap. 6, p. 179-239.

\title{
O mistério do fracasso legal: por que a lei de propriedade não funciona fora do Ocidente
}

\section{THE MYSTERY OF LEGAL FAILURE: WHY PROPERTY LAW DOES NOT WORK OUTSIDE THE WEST \\ * Isabela Cararo Lopes}

Hernando de Soto se propõe a analisar no capítulo 6 os motivos pelos quais nos países em desenvolvimento e nos antes comunistas as leis de propriedade tendem a fracassar, não atingindo um grande número de pessoas, mantendo-as na extralegalidade.

Esses países têm tentado abrir seus sistemas de propriedade, porém continuam a fracassar por possuírem algumas ideias equivocadas, como: todos os que estão fora do sistema legal querem assim permanecer para evitar o pagamento de impostos; as posses extralegais não são regularizadas por falta de levantamento, mapeamento e registro; a decretação de leis é suficiente; os acordos sociais podem ser ignorados; é possível modificar a convicção das pessoas sem uma liderança política forte.

É preciso ter em mente que as pessoas preferem se manter no sistema extralegal porque as leis não alcançam suas necessidades. Soto explica, que a clandestinidade não é isenta de custos. É por isso que para garantir uma adesão ao sistema legal, é preciso que se garanta que os custos serão menores que os da extralegalidade.

Como justificativa dessa afirmação, Soto exemplifica essa adesão com uma operação realizada no Peru que tinha como objetivo conduzir os pequenos empresários extralegais ao sistema legal de propriedade. A equipe do autor providenciou novos cartórios e sem que fosse necessário prometer uma redução de impostos, cerca de 276.000 empresários registraram suas empresas. Isso só ocorreu porque os menores custos foram garantidos, inclusive os custos burocráticos de se abrir um negócio.

* Graduada em direito pela Universidade Estadual de Londrina. Mestranda em Direito Negocial na Universidade Estadual de Londrina. Advogada. E-mail: isabela_lopes@hotmail.com 
Soto explica que existem custos dentro e fora da redoma de vidro, ou seja, na legalidade e na extralegalidade, o que determina a permanência do lado de fora, portanto, é o custo para se legalizar.

Também não é correto imaginar que os bens não podem ser registrados sem o auxílio de tecnologia de última geração, os europeus e os norte-americanos, por exemplo, o fizeram muito antes dos sistemas de informática.

Assim, o que impede mais pessoas de adentrarem à redoma de vidro é um sistema legal e administrativo ruim. É por isso que a lei deve compreender as crenças, os desejos e as regras que estão incorporados nos contratos sociais, para então transformá-los em um contrato formal nacional.

O autor confessa que fazer a transição das práticas extralegais para um sistema legal não é tarefa simples, mas foi o que as nações do Ocidente fizeram há um tempo e que possibilitou a passagem de um sistema pré-capitalista para um corpo sistematizado de leis.

É preciso fundamentar a lei no contrato social. Soto relembra que Kant já dizia que um contrato social deve preceder à posse real. Quando um grupo de pessoas apoia uma convenção em particular, as leis de propriedade totalmente desconexas com a realidade têm fadado ao fracasso, pois não possuem legitimidade.

Assim, os habitantes do exterior da redoma de vidro já estão relativamente organizados, cabendo ao governo descobrir como esses acordos funcionam, procurando meios de integrá-los ao sistema formal. É preciso entrar em contato com aqueles que vivem e trabalham sob a proteção do sistema extralegal, é preciso ir a campo e entrar em contato com as autoridades legais e extralegais locais.

Para que haja essa aproximação, Soto entende que é preciso adotar o ponto de vista dos pobres, que são o grupo que mais se beneficiará com a globalização do capitalismo.

Depois dessa etapa, as elites também devem ser convencidas dos benefícios da retirada da redoma de vidro, o que possibilitará que apoiem a reforma pelos benefícios econômicos e não somente por patriotismo e altruísmo.

Com o apoio dos pobres e da elite, é preciso lidar com o que Soto denomina como "guardiães da redoma de vidro", ou seja, os advogados e os técnicos. Para o autor, os advogados são importantes por fixarem os conceitos de propriedade. Por isso, qualquer governo disposto a integrar os sistemas, deverá contar com profissionais dispostos a encontrar uma forma legal para a reforma. 
Da mesma forma, os técnicos devem se preocupar menos com a modernização dos sistemas de propriedade e mais com a exploração dos benefícios do sistema legal.

Soto conclui dizendo que criar um sistema de propriedade acessível aos que estão dentro e fora da redoma de vidro é um desafio político, que está na mão de pessoas que devem compreender que o desafio não é criar uma legislação elegante sobre o assunto, mas sim mecanismos que possibilitem que o capital esteja nas mãos de toda a nação.

Resenha recebida em: 04/12/2014 Aprovado para publicação em: 15/02/2015

Como citar: LOPES, Isabela Cararo. O mistério do fracasso legal: por que a lei de propriedade não funciona fora do Ocidente. Scientia Iuris, Londrina, v.19, n.1, p.208-210, jun.2015. 